\title{
RESEARCH OF ENERGY EFFICIENCY AND REDUCTION OF ENVIRONMENTAL POLLUTION IN FREIGHT RAIL TRANSPORTATION
}

\author{
Sergejus Lebedevas ${ }^{1}$, Stasys Dailydka ${ }^{2}{ }^{3}$, Virgilijus Jastremskas ${ }^{3}$, Paulius Rapalis ${ }^{1}$ \\ ${ }^{1}$ Dept of Marine Engineering, Klaipeda University, Lithuania \\ ${ }^{2}$ Dept of Railway Transport, Vilnius Gediminas Technical University, Lithuania \\ ${ }^{3}$ JSC 'Lithuanian Railways', Vilnius, Lithuania
}

Submitted 28 May 2015; resubmitted 5 December 2015, 3 January 2016, 28 January 2016; accepted 21 February 2016; first published online 20 October 2016

\begin{abstract}
The publication presents the results arising from the experimental and mathematical modelling studies, which mainly aimed to investigate the selection and optimization of the rational operation modes particular to diesel engines of freight locomotives in the possession of the JSC 'Lithuanian Railways' (AB 'Lietuvos geležinkeliai'). The goal of the optimization is to increase the energy efficiency, reduce fuel consumption and emissions of harmful air pollutants to the environment from diesel engines of locomotives during freight transportation via the main lines of the Lithuanian railway network. A complex energy efficiency and environmental pollution assessment criterion $K_{E-E}$ adjusted for diesel engines of freight locomotives has been suggested. The use of $K_{E-E}$ on the basis of the conducted complex experimental mathematical computer modelling studies has determined that the reserves reducing fuel consumption, harmful emissions and greenhouse gas $\left(\mathrm{CO}_{2}\right)$ emissions constitute $6 \div 15 \%$ on an average, and in the case of individual railway network lines they go up to $30 \%$. The comparative emission of harmful components per fuel mass $\left(\mathrm{NO}_{\mathrm{x}}, \mathrm{CO}\right.$, $\mathrm{CH}, \mathrm{PM}) \mathrm{e}_{\mathrm{NO}}^{\prime}, \mathrm{e}_{\mathrm{CO}}^{\prime}, \mathrm{e}_{\mathrm{CH}}^{\prime}, \mathrm{e}_{\mathrm{PM}}^{\prime}$ when carrying freight via the main lines of the railway network by trains weighing $3000 \div 7500$ t has been singled out. The results constitute sufficient grounds to organise control of harmful emissions and provide an opportunity to solve practical tasks with a slight tolerance $(3 \div 7 \%)$ taking account of diesel engines of locomotives used for transportation. It has been proposed to measure the freight transportation efficiency according to the complex criterion $K_{E-E}$, indicates the energy efficiency and the assessment of environmental pollution originating from diesel engine of locomotives. The reserves for increasing the efficiency of energy usage have been studied according to the variational mathematical computer modelling data. A methodology for measuring the freight transportation rationality and estimating the optimal indicators has been proposed, using the values of the $K_{E-E}$ criterion for the railways freight transportation, as well as the technology for controlling the traction characteristics as well as energy and ecology indicators of diesel engines of locomotives in operational conditions.
\end{abstract}

Keywords: locomotive; diesel engine; fuel consumption; harmful component emission; mathematical modelling; operation modes.

\section{Introduction}

Railways are an economically important segment that determines the freight transportation conditions in a country and beyond. Railway transport is often the only alternative to the road transport. During the last decade, the EU has been focusing on growing flows of road transport and related problems. One of the most important issues is the increase in the energy efficiency in vehicles (EC 2003). In particular, energy consumption per work unit expressed in [t.km] (tonne kilometres) for vehicles are taken into consideration. The environmental protec- tion immediately related to energy efficiency is no less important. The largest emission of greenhouse gas and harmful components from vehicles are also specifically expressed in $[\mathrm{t} \cdot \mathrm{km}]$. In order to improve the situation, EU states have significantly increased the road transport taxes during the last decade, thus encouraging the use of several alternative transport modes, firstly water and railway (EC 2011). In parallel with this decision, international railway associations (Eggleston, Walsh 2000) the Community of European Railway and Infrastructure Companies (CER), International Association for Public

Corresponding author: Paulius Rapalis

E-mail: PauliusRapalis@gmail.com 
Transport (UITP), Association of the European Rail Industry (UNIFE) - have decided to increase the market share from 6 to $10 \%$ by 2020 , at the same time reducing the air pollution by up to $50 \%$. When transporting freight for more than $300 \mathrm{~km}$, the aim is to replace $30 \%$ of road transport by 2030 and more than $50 \%$ of road transport with other transport types, including railway (EC 2011). This tendency is determined by the peculiarities of railway transport. Compared to other transport modes, the railway transport is more environmentally-friendly as it emits a significantly lower quantity of harmful components into the atmosphere, as well as a lower amount of greenhouse gas both in absolute units and per performed work unit, which is transported freight per distance unit, [t.km] (Fig. 1). This figure may be used under the same conditions to assess the energy efficiency of vehicles of different types as $\mathrm{CO}_{2}$ emissions when using fuels of petroleum origin (with a similar element composition) depend on the amount of fuel used.

Railway transport plays an especially significant role in Lithuania. In this country, railway freight flows in 2012 amounted to $40.9 \%$ of the overall freight. The main transport corridors through the Republic of Lithuania go North-South (Pan European Transport Corridor I), the Rail Baltica Corridor and East-West (Pan European Transport Corridor IX). The main freight flows go to Belarus and Klaipeda Port (Statistics Lithuania 2015). For comparison, in 2011, the EU railways ensured 11\%
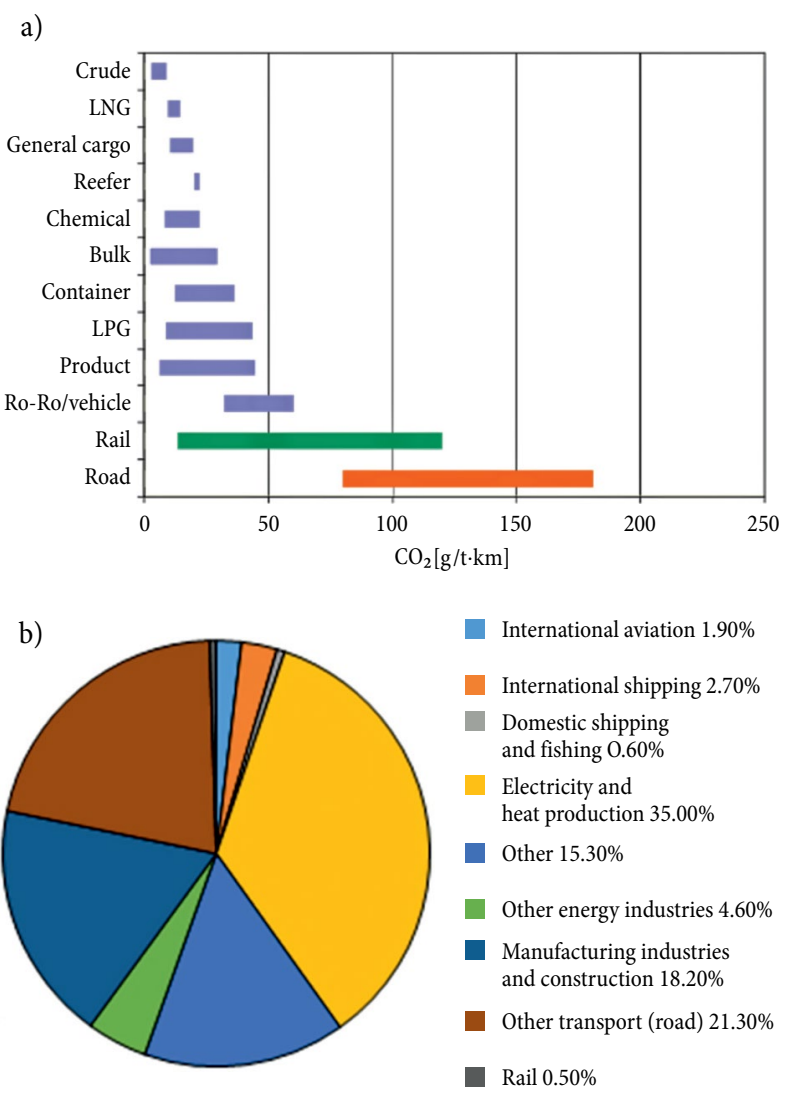

Fig. 1. Specific $\mathrm{CO}_{2}$ emissions [g/t.km] (a) and $\mathrm{CO}_{2}$ emissions [\%] from vehicles in the overall global balance (b) (IMO 2009) of the import/export from the EU 27 and $6.5 \%$ of the overall freight flows (EC 2013).

Since Lithuania joined the EU in 2004, significant changes happened in the railway transport sector, including a radical renewal of operational rolling stock. The JSC 'Lithuanian Railways' modernised operational diesel engines, replacing the M62 and 2M62 with new and re-motorized locomotive series.

The old-generation M62/2M62 locomotives with low-efficiency morally outdated two-stroke diesel engines $\mathrm{D} 40$ were replaced by modern models: the $2 \mathrm{M} 62 \mathrm{~K}$ locomotives with the D49 series diesel engines, the 2M62M and ER20CF/2ER20CF locomotives with modern four-stroke diesel engines, the 12-cylinder diesel engine CAT-3512B-HD and 16 cylinder diesel engine MTU 4000R41 (MTU 16V4000R41) diesel engines respectively. The CAT3512B-HD and MTU 4000R41 diesel engines with electronic control system met the norms of the applicable UIC II standards (DieselNet 2015). After assessing the energy efficiency of the locomotives currently operated by JSC 'Lithuanian Railways', it can be stated that an operation of the $2 \mathrm{M} 62 \mathrm{~K}$ locomotives is substantially limited. Only 2 locomotive series are actually used for freight transportation: the $2 \mathrm{M} 62 \mathrm{M}$ and ER20CF/2ER20CF. It is necessary to mention that in the Western countries including the US, the Caterpillar company's CAT 3512B-HD and German company's MTU 16V4000R41 diesel engines, due to their rather similar operational characteristics, are alternatively used in a number of locomotives - Caterpillar 3512B locomotive engine, see Vossloh North America (2015). However, conditions of the rolling stock operating in Lithuania are very different from those in the Western European countries: short freight transporting distances, complex line profile, big freight flows and accordingly bigger loads for diesel locomotives. All of this negatively affects the reliability indicators of diesel engines: the operation time warranted by a manufacturer decreases, while the risk of the problems and failures of units and systems increases. The locomotive reliability tests have been carried out on this basis, in order to evaluate the actual resource (Lingaitis et al. 2014). Since there are no diesel engine production and modernisation technologies in Lithuania, also taking into account the terms of warranty, the optimisation of operational cycle indicators has become the main method for improving diesel indicators. According to the research results, an increase of the freight diesel locomotive operation time by $7 \div 10 \%$ is predicted.

Main principles of the performed research are based on specifics of Lithuanian railway lines. Lithuania has a limited number of railway lines that are used for cargo transfer. The main traffic occurs on: line I - the international cargo corridor Moscow-Kaunas-Šiauliai; IA corridor - going to the Kaliningrad Region (starts at Vaidotai distribution station to Kybartai station) and IX corridor - with two branches of the international railway (IXB - Kena-Vilnius-Klaipèda and IXD - KaišiadorysKaunas-Kybartai). 


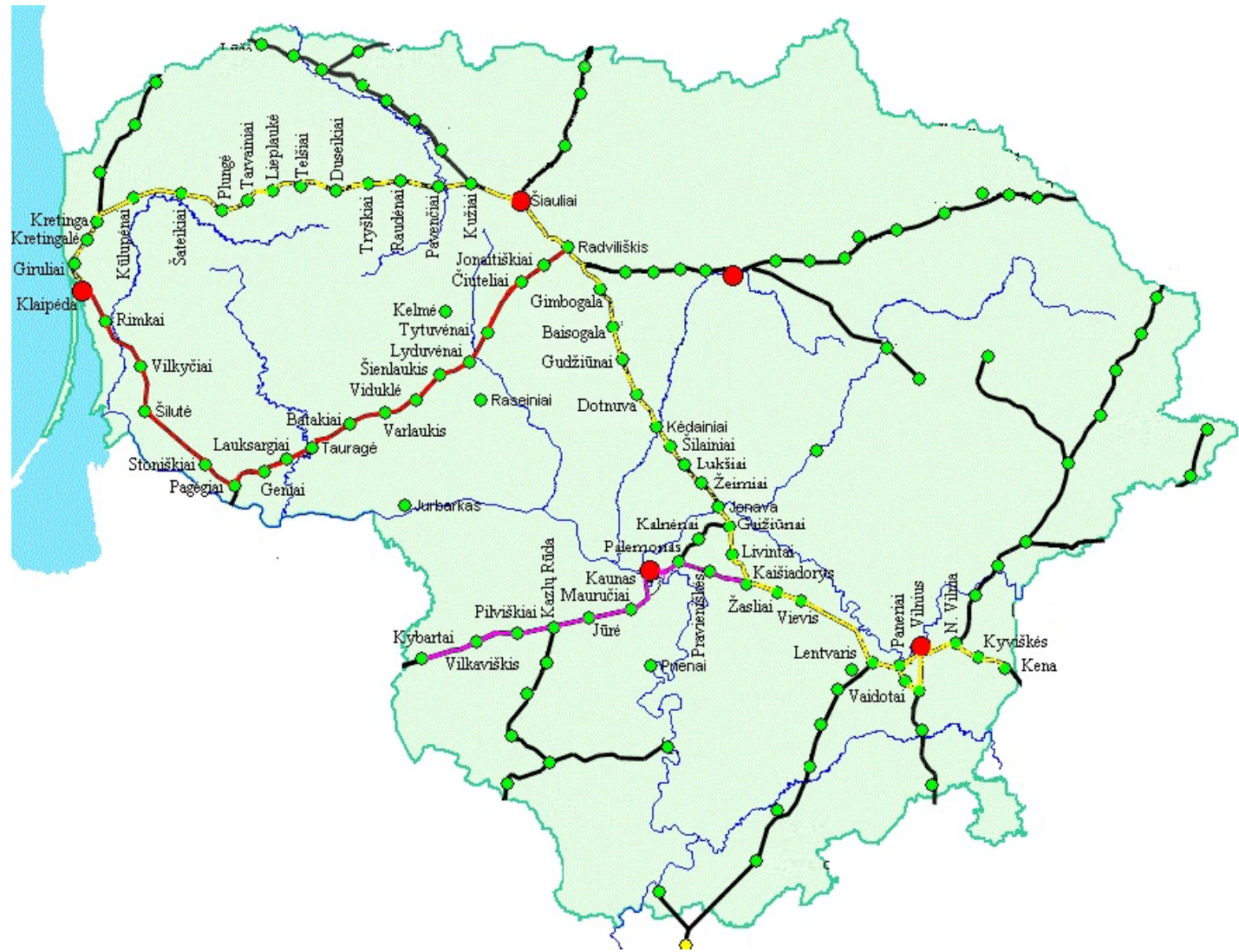

Fig. 2. Lithuanian railway lines (Parovoz IS 2015)

The rolling stock fleet of JSC 'Lithuanian Railways' used on the main lines has little variety as it consists of three types of locomotives: re-motorised $2 \mathrm{M} 62 \mathrm{~K}$ with 2-2D49 series, modernised 2M62M (UM) with CAT 3512B-HD series and the new ER20CF with MTU 4000R41 series. Out of the three diesel engines, the following are in operation: CAT 3512B-HD and MTU 4000R41. 2-2D49 diesel locomotives were moved to the reserve of the company.

Based on this, it was logical to perform the mathematical modelling and experimental research on harmful emissions from 2M62M and ER20CF/2ER20CF locomotives operating on specific railway lines. In addition, a single trip was planned to investigate the efficiency and the level of harmful emissions from an operated locomotive.

Taking into account the strategic direction of the transport sector development, the major focus is placed on the maximum optimisation of transport efficiency and ecology, including complex analysis (González-Gil et al. 2013, 2014) and modelling (Kirschstein, Meisel 2015) of rail transport as well as research of individual transportation elements - locomotives (Li et al. 2009; Shancita et al. 2014) and heavy diesel engines (Katsanos et al. 2013). The complexity of rational freight transportation indicators is equally important, taking into account the energy, environmental, reliability indicators and reducing the fuel consumption and harmful components emissions. A key component of this study is the complex experimental (under real operational con- ditions) and mathematical modelling research of the energy and ecology indicators of diesel engines of freight locomotives operated by the JSC 'Lithuanian Railways'. The main goal of the research was:

- to examine the reserves for reducing the energy (fuel) consumption and harmful emissions (as well as the greenhouse gas emissions) to the environment when transporting freight under the conditions of the Lithuanian railway line;

- assess and approve the measures for improving the operational energy and ecology indicators of diesel engines of freight fleet locomotives, and the technologies for the practical application of these measures.

\section{Research Methodology}

The fuel consumption and harmful emissions from diesel engines of freight locomotives operated by the JSC 'Lithuanian Railways' have been calculated using the mathematical modelling software package created and adapted by the authors. In this package, the energy and ecology indicators of diesel engines under real operational conditions are modelled for a specific freight transportation trip. The base of the calculation algorithm is made of the classic thrust calculation methods and energy and ecology indicator data in modes of the locomotive characteristics, which is provided by diesel engine manufacturers. The adequacy of using the mathematical modelling complex is confirmed by comparative experi- 
ments: calculation tests, for example, fuel consumption by diesel engines of locomotives assessed and registered during a trip, differs by no more than $4 \div 6 \%$. (Lingaitis et al. 2014; Lebedevas et al. 2015).

Adequacy of pollution research has been justified: on the one hand, by the modelling accuracy of engine energy indicators under operational conditions, and on the other hand, by the use of ecology characteristics of engines provided under locomotive characteristics by actual engine manufacturers in the modelling software package.

In practice, there is a widespread method for assessing harmful components $\left(\mathrm{NO}_{\mathrm{x}}, \mathrm{CO}, \mathrm{CH}, \mathrm{PM}\right)$ emitted by internal combustion engines according to the comparative emission indicators per unit of a diesel fuel mass used by a locomotive engine $\mathrm{e}_{\mathrm{NOx}}, \mathrm{e}_{\mathrm{CO}}, \mathrm{e}_{\mathrm{CH}}$, $e^{\prime}{ }_{P M}[\mathrm{~g} / \mathrm{kg}$ of fuel] or $[\mathrm{kg} / \mathrm{t}$ of fuel]. The main advantage of this method is a possibility to quickly control and evaluate the environmental pollution originating from diesel engines of locomotives with an acceptable accuracy of practical solutions, assessing the pollution according to the operating fleet's fuel consumption per certain period. The pollution reduction objectives in the transport sector are generally fulfilled by establishing the transport company compensatory payments for environmental pollution (LR AM 2011a, 2011b; Winther 2008). Therefore, the carriers are interested in controlling the amounts of vehicle engine exhaust emissions. The same applies to diesel engines of locomotives. However, a practical implementation of this method has significant drawbacks as well.

Most methodologies for the application of this method calculate the engine fuel consumption according to the regulated test cycle structure of the ISO 81789:2012 standard. However, as a general rule, both the actual load cycle structure (diesel engine load - operation time) and the average operating load substantially differ from the ISO 8178-9:2012 standard data. Due to the same reason, the specific average values of the test and actual specific emission of harmful components during an operational cycle (calculated $\mathrm{e}_{\mathrm{NO}}^{\prime}, \mathrm{e}_{\mathrm{CO}}^{\prime}, \mathrm{e}_{\mathrm{CH}}^{\prime}, \mathrm{e}_{\mathrm{PM}}^{\prime}$ $[\mathrm{g} / \mathrm{kg}$ of fuel]) differ as well. In order to ensure the adequacy of the calculation results to the operational data, the methodologies often use various correction factors without clear physical basis. This can be regarded as an additional source of calculation errors.

The accounting of harmful emissions to the environment originating from diesel engines of the rolling stock operated by the JSC 'Lithuanian Railways' is done according to the provisions of LAND 18-2011 'Methodology for calculating the amount of air pollution emitted by railway rolling stock with diesel internal combustion engines', the edition of 2011 (LR AM 2011b). The author assessments have shown that the component emissions from diesel engines of locomotives, calculated according to the LAND 18-2011 and the manufacturers' as well as actual operational cycle indicators differ from $20 \div 15 \%$ or up to 4 times (in some individual cases) (LR AM 2011b). In order to control emissions and form environmental protection measures, it is advisable for the JSC 'Lithuanian Railways' to install complex technolo- gies of mathematical modelling and experimental data registering, the basis of which would be the actual load cycle indicators of a diesel engine of a locomotive.

In this research, emissions of harmful components originating from diesel engines of freight locomotives operated by the JSC 'Lithuanian Railways' have been calculated by using mathematical modelling software package developed by the authors. In this software package, diesel engine energy and ecology indicators were modelled specifically for a certain freight forwarding. The calculation algorithm was based on the classic traction methods and engine manufacturers' data on energy and environmental data on engines in locomotive performance modes. The use of the mathematical modelling package has confirmed the adequacy of comparative experiments, for example, the difference between the calculated and registered diesel fuel consumption varies by not more than $4 \div 6 \%$

Another important aspect of the study has been a research on the influence transition modes of a diesel engine of a locomotive on the energy indicators. As already known, the transport diesel engines, including the ones of locomotives, most of the time operate in transient modes (Simson et al. 1987; Homich 1987; Lingaitis et al. 2014). As mentioned above, the $2 \mathrm{M} 62 \mathrm{M}$ and ER20CF/2ER20CF locomotives with the CAT 3512BHD and MTU 4000R41 diesel engines controlled by an electronic system (ECS) are mainly operated at this time. Namely, the use of ECS for a transport diesel engine is meant for reducing the influence of transient processes on the operational indicators. However, the efficiency of these systems must be assessed under real locomotive operational conditions, when transporting freight via the Lithuanian railway lines. The results of transient operation modes are provided in the publication by the authors in more detail (Lebedevas et al. 2015).

According to the results of experimental studies, the efficient functioning of Electronic Control Unit (ECU) is one of the main factors influencing emissions as the excess air factor $\alpha$ in transient modes differs by not more than $3 \div 5 \%$ in comparison with similar steadystate modes. Based on these results, authors intend to perform 2 stages. Results of the first stage are published in this paper. The second stage of the research will be carried out in order to analyse the impact of transient operating modes on the ecological and economic indicators of operating conditions.

\section{Substantiation of the Optimisation Criterion of Energy and Ecological Indicators of Freight Transportation of the JSC 'Lithuanian Railways'}

For a long time, in rail practice, rationing of energy flows and same reduction methodologies have been based on classical traction calculations (MPS RF 1997; Simson et al. 1987), and statistical indicators of the freight process, revealing the technical perfection of locomotive equipment (wagons, rails, etc.). It is the classical theory and experimental and operational statistics that ensure the relevance of this methodology in the absence of scientific novelty. The following analysis aims to reveal the 
main energy utilisation efficiency of railway transportation issues.

For the control and rate-setting of the energy resources in railway transport (including Lithuania) or transportation work for a $10000 \mathrm{t} \cdot \mathrm{km}$ unit (MPS SSSR 1967; MPS RF 1997; AB 'Lietuvos geležinkeliai’ 2003) consumed in diesel engines, the indicator $N_{w}$, has been successfully used for a long time.

The analytical dependence of $N_{u}$ indicator includes all of the components of the freight and passenger transportation process, having an influence on energy consumption: energy indicators of a diesel engine of a locomotive, technical indicators of the rolling stock, relief indicators of the transportation line, etc. The coefficients used in the methodology for the calculation of the $N_{u}$ indicator had been systematically specified according to the exploitation data, as the infrastructure technologies of the rolling stock had improved. With all the practical realisation advantages of the methodology, its effectiveness depends on the statistical data of all levels, i.e. the collection, analysis and generalisation system. The energy consumption control method on the basis of the $N_{u}$ indicator is practically impossible due to the control of the railway system components, the functioning control, and infrastructure decentralisation.

However, it is expedient to carry out an analysis of the aforementioned methodology, by simultaneously singling out the main factors from amongst many factors influencing the $N_{u}$ factor, whose control is accessible to JSC 'Lithuanian Railways' when transporting freights. This task has been sufficiently analysed (Lebedevas 2002). A complex solution of the energy resource preservation in railway transportation has been analysed by optimising the regulation of diesel engines of locomotives and their modes in the implementation of the created information technology, rational cargo transportation parameter determination software, which specialises in control and rate-setting and is used for the control and technical maintenance infrastructures.

\section{Analysis of Factors Constituting Energy Consumption Limit Values in Rail Transport}

The standards for the use of diesel in locomotive engines operated by the JSC 'Lithuanian Railways' are regulated by the company's methodology 'The Methodology For Determining Limit Values of Diesel in Locomotives and Diesel Trains' (AB 'Lietuvos geležinkeliai' 2003). The methodology has been developed based on regularly updated standards (MPS SSSR 1967; MPS RF 1997), where the structure of consumed energy resources is:

$$
\begin{aligned}
& N_{u}=\frac{A_{T}}{Q \cdot \eta_{l n}} \cdot\left(K_{x} \cdot b_{x} \cdot \frac{N_{n}}{V}+\right. \\
& \left.\frac{K_{t p}-K_{x} \cdot b_{x}}{367.2} \cdot(P+Q) \cdot\left(\omega_{o}+i\right)\right),
\end{aligned}
$$

where: $N_{u}$ is the initial technical limit value of comparative fuel [kilograms $10000 \mathrm{t} \cdot \mathrm{km}$ per gross unit]; $A_{T}$ - traction index (electric traction - 10000, thermal traction -843 or 1222.4 to measure the fuel consumption by natural or comparative units, respectively); $\eta_{l n}-$ nominal locomotive efficiency factor; $Q$ - train cargo mass $[\mathrm{t}] ; K_{x}$ - locomotive ancillary consumer power consumption factor at idling speed; $b_{x}$ - comparative consumption of a source of energy (usually diesel) at idling speed, equal to an hourly fuel consumption ratio at idle $B_{x}$ and nominal $B_{n}$ modes $\left(\bar{b}_{x}=B_{x} / B_{n}\right) ; N_{n}$ rated locomotive tangential power $[\mathrm{kW}] ; V$ - average route technical speed $[\mathrm{km} / \mathrm{h}] ; K_{t p}$ - locomotive technical condition factor, equal to a ratio of actual and hourly fuel consumption of a locomotive technical passport at nominal mode; $P$ - locomotive mass $[\mathrm{t}] ; i$ - additional gradient specific resistance; $\omega_{o}$ - comparative core resistance, train movement, and set by the formula:

$$
\omega_{o}=\frac{P \omega_{o}^{\prime}+Q \omega_{o}^{\prime \prime}}{P+Q},
$$

where: $\omega_{o}^{\prime}, \omega_{o}^{\prime \prime}$ - core specific resistance of a locomotive and railcar determined by empirical equations for a function based on technical characteristics of the train speed, road and railcars.

It is important to single out prevailing factors from amongst the major factors, which are difficult to be practically determined by the dependence; and it is especially important to single out the factors, which are directly related to technical characteristics of a diesel engine of a locomotive. This would mean the basis for determining rational directions when standardising and controlling energy resources in the rail transport system (Lebedevas 2002).

According to the equation, the $N_{u}$ dimension consists of two sides: fuel consumption for the operation of ancillary consumers (cooling system fan, ancillary generators, and compressor) and fuel consumption for the $Q$ mass train movement at route technical speed $V$ (second summand of the right-hand side). Where both sides of the Eq. (1) are multiplied by $Q / A_{T}$, the first summand of the right-hand side is expressed as:

$$
K_{x} \cdot \bar{b}_{x} \cdot N_{n}=(0.5 \div 1.0) \cdot \frac{B_{x}}{B_{n}} \cdot \frac{B_{n}}{b_{n}}=\frac{(0.5 \div 1.0) B_{x}}{b_{n}},
$$

where: $B_{n} / b_{n}$ - rated locomotive power $[\mathrm{kW}] ; B_{n}$ - fuel consumption in nominal power mode $[\mathrm{kg} / \mathrm{h}] ; b_{n}$ - specific fuel consumption $[\mathrm{kg} / \mathrm{kWh}]$; multiplier $(0.5 \div 1.0)$ is auxiliary equipment (locomotive cooling systems, fans, compressors) load factor.

This summand shows fuel consumption of ancillary units, which equals a comparative fuel consumption unit at rated power mode. The second summand of the right-hand side is expressed as follows once put in brackets and multiplied:

$$
\begin{aligned}
& V \cdot \frac{1}{\eta_{l n}} \cdot \frac{\left(K_{t p}-K_{x} \bar{b}_{x}\right)}{367.2} \cdot(P+Q) \cdot\left(\omega_{o}+i\right)= \\
& \left(\frac{B_{n}^{f}}{B_{n}}-(0.5 \div 1.0) \frac{B_{x}}{B_{n}}\right) \cdot \frac{1}{367.2} \times \\
& \frac{V \cdot(P+Q) \cdot\left(\omega_{o}+i\right)}{\eta_{l n}} \cdot \frac{P_{V}}{P_{n}},
\end{aligned}
$$


where: $\frac{V \cdot(P+Q) \cdot\left(\omega_{o}+i\right)}{\eta_{l n}}$ multiplier marked $P_{V}$ corresponds to the diesel engine power consumed for train movement; $\omega_{o}$ is the resistance to movement; $\eta_{l n}$ - nominal locomotive efficiency factor. Parallel to the factor, a ratio factor is called a diesel engine duty factor for movement of a train of rated power. The primary multiplier of the Eq. (4) is the hourly fuel consumption by a diesel engine for movement divided by $b_{n}$. This change results in:

$$
\frac{N_{u} \cdot Q \cdot V}{A_{T}} \approx \frac{B_{x}+K_{v} \cdot B_{v}}{b_{n}},
$$

where: $K_{v}$ - factor of diesel engine nominal capacity utilization for movement of the train; $B_{v}$ - fuel consumption in exploitation mode $[\mathrm{kg} / \mathrm{h}]$.

The Eq. (3) shows an hourly limit of comparative fuel consumption. Basically, to have the fuel consumption limits (3), the equation is multiplied by diesel engine specific effective fuel consumption which, under initial conditions, is taken as constant in the whole field of diesel engine operation modes:

$$
\frac{N_{u} \cdot Q \cdot V \cdot b_{n}}{A_{T}} \approx B_{x}+K_{v} \cdot B_{v} .
$$

Operational fuel consumption is formed by locomotive diesel engine operational load modes whole indicator $P_{v i}$ relevant values at $i$-th operation mode (the position of the controller of the locomotive control system) - operational load cycle - and specific fuel consumption indicators $b_{v i}$ in these modes (Simson et al. 1987).

Thus, energy resources of the fleet operated by diesel engines of locomotives relate to and characterise average operational dimensions (Simson et al. 1987):

$$
\begin{aligned}
& b_{v}=\frac{\sum_{i=1}^{n} b_{v i} \cdot P_{v i} \cdot \tau_{i}}{\sum_{i=1}^{n} P_{v i} \cdot \tau_{i}} \\
& P_{v}=\sum_{i=1}^{n} P_{v i} \cdot \tau_{i},
\end{aligned}
$$

where: $b_{v i}$ - specific fuel consumption indicators at $i$-th operation mode; $P_{v i}$ - indicator relevant values at $i$-th operation mode (the position of the controller of the locomotive control system); $\tau_{\mathrm{i}}$ - comparative diesel engine operation time at $i$-th mode.

The reduction of diesel engine fuel consumption by various operation modes is ensured in two ways: first the improvement of an indicative process; second - the selection of a rational structure of an engine load range, i.e. where fuel consumption is as low as possible, and $P_{v}$ is as high as possible under the conditions of technical indicators of the ride.

The research for selecting rational indicators for freight transportation by JSC 'Lithuanian Railways' via the lines of the railway network has been conducted by means of the complex criterion:

$$
K_{E-E}=\frac{B \cdot H_{u}}{Q \cdot L},[\mathrm{~kJ} /(\mathrm{t} \cdot \mathrm{km})]
$$

which is analogous to $N_{u}$. The 'energy value' $[\mathrm{kJ} / \mathrm{t} \cdot \mathrm{km}]$ of the criterion, where $B \cdot H_{u}$ is the chemical energy of fuel ( $B$ - fuel consumed per trip $[\mathrm{kg}] ; H_{u}$ - lower calorific value of fuel $[\mathrm{kJ}]) ; Q$ - train weight $[\mathrm{t}] ; L$ - distance $[\mathrm{km}] ; K_{E-E}$ when compared to a standard amount of consumed fuel per freight transportation work unit $[\mathrm{kg}$ of fuel $/ \mathrm{t} \cdot \mathrm{km}]$ provides the grounds for the following studies:

- comparative evaluation of efficiency of the use of alternative types of fuel (biodiesel, liquefied natural gas, compressed natural gas, etc.) in the rolling stock fleet;

- research of technology of alternative sources of energy (solar batteries, kinetic energy accumulation systems, etc.).

\section{Research on the Comparative Harmful Component Emission}

An analysis was performed of the harmful component emission of the D49 12 cylinder diesel engine (locomotive $2 \mathrm{M} 62 \mathrm{~K}$ ), CAT $3512 \mathrm{~B}-\mathrm{HD}$ (locomotive $2 \mathrm{M} 62 \mathrm{M}$ ) and MTU 4000R41 (one- and two-section locomotives ER20CF/2ER20CF) locomotive diesel engine exhaust on the main freight transportation lines: Kena-Vaidotai-Kybartai, Bugeniai-Klaipeda/Draugystè, KenaVaidotai-Kaišiadorys-Radviliškis-Šiauliai-Klaipèda/ Draugyste (when the train weight is $3000 \div 7000 \mathrm{t}$ ). Fragments of the research results are shown in Fig. 3.

Naturally, the operational ecology indicators of different locomotive series, showing the emission of many harmful components, differ by up to $2 \div 3$ times. The comparative locomotive engines D49, CAT 3512B-HD and MTU 400R41 are certified according to different standards for the regulation of ecology indicators. For the practical application of the research results, it is important that emissions of a specific harmful component emitted by the same locomotive series (HCSE - Harmful Component Specific Emission), recalculated per fuel consumption unit, practically remain the same even when the train weight differs, as well as, in most cases, a railway line. The results are mostly influenced by: the technical level of excellence (for the ecology indicators) of comparative locomotive engines, the HCSE change character in the power range of a diesel engine; the operational load cycle structure of a diesel engine when transporting freight via a certain railway line; diesel engine transition mode influence on the increase in the harmful component emission and reduction of this influence by the diesel engine control system (Kolomensky Zavod 2015; Caterpillar 2015; Rakopoulos, Giakoumis 2009; Rakopoulos et al. 2010; Lebedevas 2002; Katsanos et al. 2013).

For example, according to the data of the MTU 4000R41 diesel engine manufacturer Motoren Und Turbinen Union (Fridrichshafen), the specific $\mathrm{NO}_{\mathrm{X}}, \mathrm{CO}$ and $\mathrm{CH}$ emissions for HCSE, when the diesel engine power $P_{e}$ ranges from idle to almost the maximum, are close 

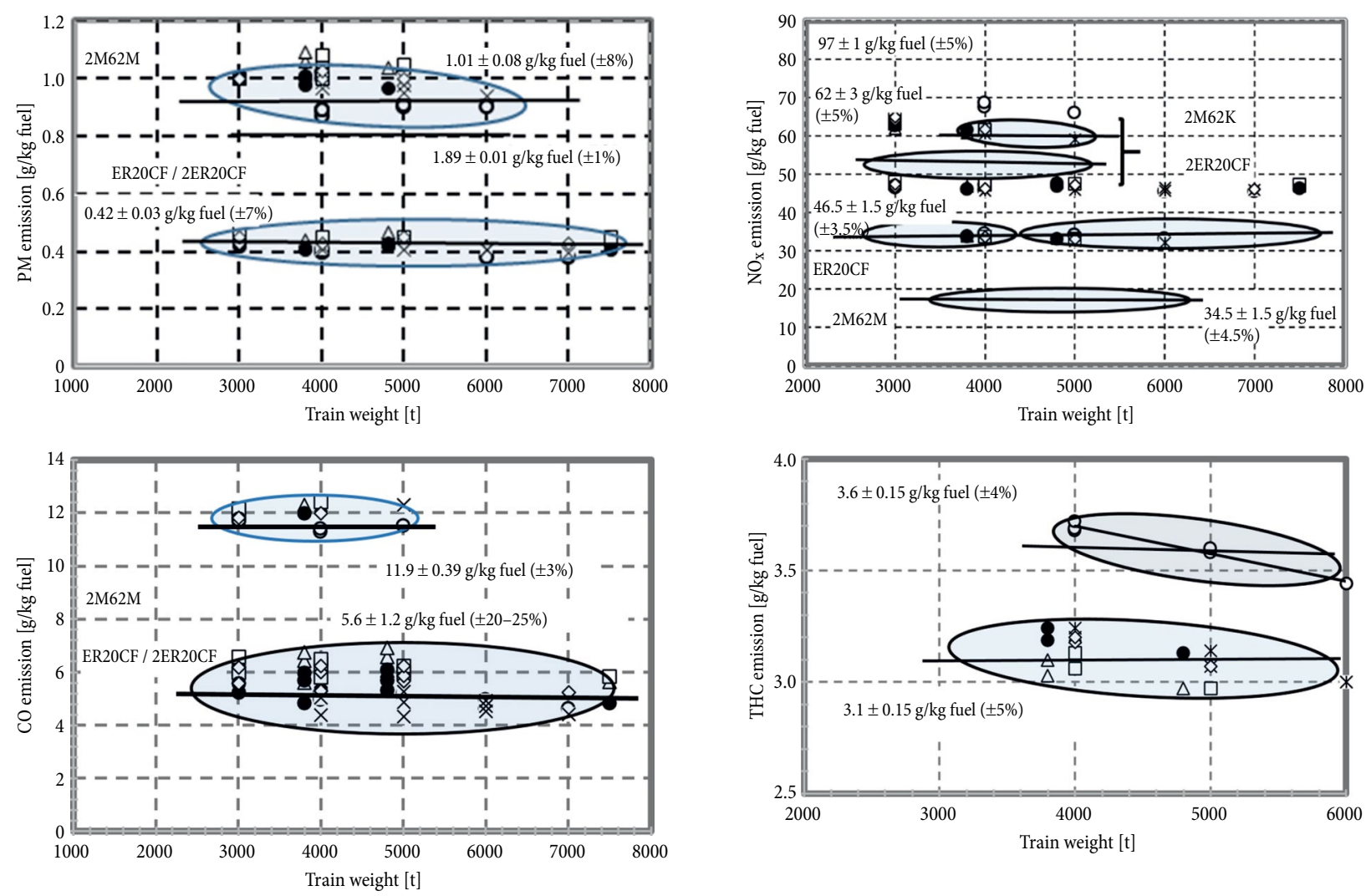

$\begin{array}{ll}\bullet \text { Kena-Vaidotai } & \square \text { Vaidotai-Radviliškis } \\ \times \text { Vaidotai-Kybartai } & \bullet \text { Radviliškis-Klaipèda, Draugystė (trough Kužiai station ) } \\ \Delta \text { Bugeniai-Klaipeda-Draugystė } & \diamond \text { Radviliškis-Klaipèda (trough Pagègiai station) }\end{array}$

Fig. 3. Ecology indicators of diesel engines of freight locomotives (HCSE [g/kWh]) operated by the JSC 'Lithuanian Railways'

to the parabolic dependence: the minimal values are achieved under the idle and nominal power modes, with the maximum being in a rather wide range of the average load, from 30 to $80 \%$ of the maximum power. The emissions of solid particles (PM) increase evenly, but not significantly, with the increase in the power. The change character close to HCSE is characteristic to the CAT 3512B-HD diesel engine. The D49 diesel engine's HCSE dependency differs from the power dependency significantly when compared to the CAT 3512B-HD and MTU 4000R41 diesel engines: the $\mathrm{NO}_{\mathrm{x}}$ and $\mathrm{CH}$ maximums are achieved during idle run, they decrease up to the maximum power modes in the hyperbolic dependence form with the increase of $P_{e}$; and vice versa, the $\mathrm{CO}$ and $\mathrm{PM}$ emissions increase with the increase in the diesel engine load.

On the other hand, when the weight of transported freight increases, the diesel engine load increases as well, and the operational load cycle structure changes accordingly.

As a result, the proportion of the average and almost-maximum power operational modes increases. Thus, when the train weight increases from 5000 to $7500 \mathrm{t}$ on the Vaidotai-Kybartai line, the load cycle of the 2ER20CF locomotive diesel engines changes substantially (Fig. 3, a fragment of the mathematical modelling results for freight transportation), the operation time of the diesel engine in idle run decreases from 34 to $13 \%$ in the balance of the entire trip, while the operation in the maximum power modes increases from 0 to $24 \%$. Thus, the redistribution of the operation modes between the maximum and idle power has occurred. The operation time in the average load modes has also changed towards the higher-load modes: when the train weight is up to $5000 \mathrm{t}$, the engine operates at the maximum power modes from 10 to 50 for up to $55 \%$ of the entire time of the trip; when the train weight is $7500 \mathrm{t}$, the engine works for around $50 \%$ of the same trip's time, with the load of $20 \div 70 \%$ of the maximum power.

Taking into account the assessed changes related to HCSE, the average HCSE values per trip should not change substantially. The same was shown by the mathematical modelling results. With minor exceptions, the HCSE indicators of individual harmful components for specific locomotive series $(2 \mathrm{M} 62 \mathrm{~K}, 2 \mathrm{M} 62 \mathrm{M}$ and ER20CF/2ER20CF) could be regarded as constants for practical use, irrespective of a freight transportation line (Table).

The obtained results allow the assessment and control of harmful emissions originating from diesel engines of locomotives under conditions of freight transportation with a rather high accuracy of practical task solving amounting to $3 \div 7 \%$. The possibility is ensured to assess the indicators for freight transportation energy and ecology, efficiency indicators as well as greenhouse gas $\mathrm{CO}_{2}$ emissions, for different locomotive series on individual lines, according to a specific fuel consumption. 


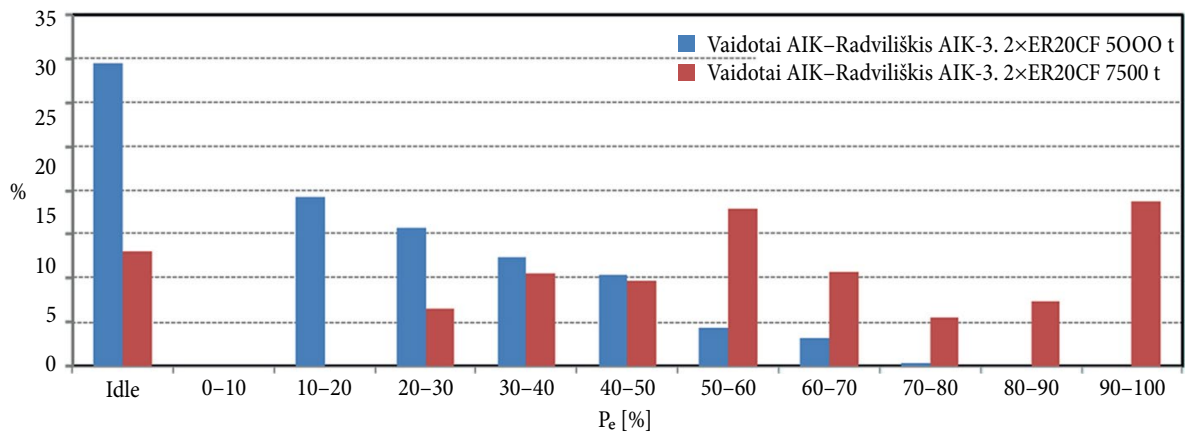

Fig. 4. Operational load cycle structure of the 2ER20CF locomotive diesel engine on the line Vaidotai-Radviliškis (train weight $5000 \mathrm{t}$ and $7500 \mathrm{t}$ )

Table. Comparative harmful component emission originating from diesel engines of freight locomotives operated by the JSC 'Lithuanian Railways' on the main railway network lines

\begin{tabular}{|c|c|c|c|c|}
\hline \multirow{2}{*}{$\begin{array}{l}\text { Engine model } \\
\text { (locomotive) }\end{array}$} & \multicolumn{4}{|c|}{ Specific emission of a pollutant $[\mathrm{g} / \mathrm{kg}$ of fuel $]$} \\
\hline & $\mathrm{e}_{\mathrm{NOx}}^{\prime}$ & $\mathrm{e}_{\mathrm{CO}}^{\prime}$ & $\mathrm{e}_{\mathrm{CH}}^{\prime}$ & $\mathrm{e}_{\mathrm{PM}}^{\prime}$ \\
\hline D49 (2M62K) & $(62 \div 67) \pm 3$ & $11.9 \pm 0.3$ & $(5.2 \div 5.7) \pm 0.3$ & no data \\
\hline $\begin{array}{l}\text { CAT 3512B-HD } \\
(2 \mathrm{M} 62 \mathrm{M})\end{array}$ & 34.515 & $(5 \div 6) \pm 0.4$ & $(3.1 \div 3.6) \pm 0.15$ & $1.01 \pm 0.08$ \\
\hline $\begin{array}{l}\text { MTU 4000R41 } \\
\text { (ER20CF/2ER20CF) }\end{array}$ & $46.5 \pm 1.5$ & $(4.5 \div 6.0) \pm 0.5$ & $(2.9 \div 3.25) \pm 0.1$ & $0.42 \pm 0.03$ \\
\hline
\end{tabular}

The created technology for mathematical modelling of operational indicators of diesel engines of locomotives is intended to be used for the assessment of ecology indicators of diesel engines of operational locomotives, while in the longer run - for substantiating the renewal of the locomotive fleet.

Yet another important aspect of the research was the comparison of the actual emissions and their standard norms during the operation on a real line of the Lithuanian railway network.

\section{Rational Indicator Modelling of Cargo Carrying Aimed at the Increase of Energy Efficiency and the Reduction of Environmental Pollution}

Fragments of variational mathematical modelling results, determining the value of $K_{E-E}$ criteria on the main lines of the railway network are given in Figs 5 and 6 . The graphical material in the pictures has been grouped from the starting point to the destination of freight transportation.

The achieved results witness the significant differences in energy efficiency on different lines with a view to the train weight and type of a locomotive.

Energy efficiency of locomotives of all types increases by increasing the train weight; however, the intensity of such an increase differs in the case of different types of locomotives; e.g. the increase of the train weight by $100 \mathrm{t}$ reduces the value of the energy efficiency and ecology criterion $K_{E-E}$ for the locomotive $2 \mathrm{M} 62 \mathrm{~K}$ by $8.5 \%$, by $7 \%$ for locomotives $2 \mathrm{M} 62 \mathrm{M}$ and $2 \mathrm{ER} 20 \mathrm{CF}$, and by $11 \%$ for single-section locomotive ER20CF on the line Bugeniai-Klaipeda/Draugyste (Fig. 4); on the line section Radviliškis-Klaipeda (via Pagègiai station) $K_{E-E}$ changes constitute $6.5 \%, 6 \%$ and $3.5 \%$, respectively.

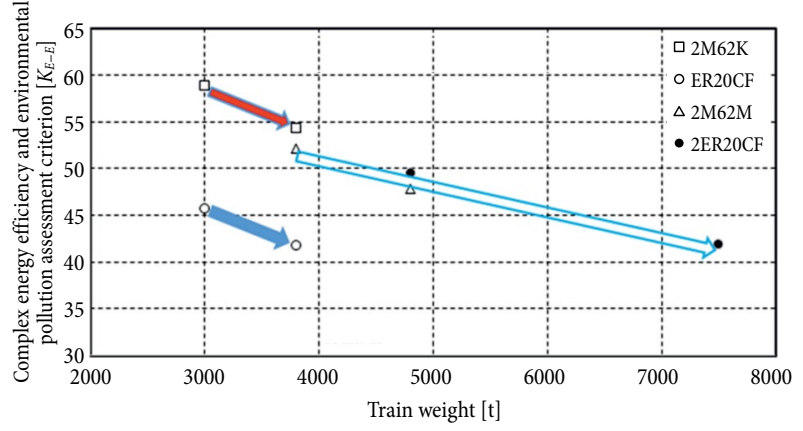

Fig. 5. Evaluation of energy efficiency on freight transportation line Bugeniai-Klaipeda/Draugystè

Energy efficiency is basically equivalent when carrying freight by locomotives $2 \mathrm{M} 62 \mathrm{M}$ and $2 \mathrm{ER} 20 \mathrm{CF}$, where the train weight is the same; this way, the use of diesel engines CAT 3512B-HD and MTU 4000R41 in locomotives of the US railway companies is justifiable (due to identical operation indicators) (Vossloh North America 2015).

When pulling trains of the limit weight (by diesel engine power), the energy efficiency of the single-section locomotive ER20CF is higher than that of locomotives $2 \mathrm{M} 62 \mathrm{~K}$ and $2 \mathrm{M} 62 \mathrm{M}$ on all lines: e.g. on the section Kena-Vaidotai, up to $30 \%$ when compared to $2 \mathrm{M} 62 \mathrm{~K}$ and up to $20 \%$ when compared to locomotives $2 \mathrm{M} 62 \mathrm{M}$.

As the whole, energy efficiency of the locomotive $2 \mathrm{M} 62 \mathrm{~K}$ on all freight transportation lines of JSC 'Lithuanian Railways' is significantly lower than that of modern locomotive models, especially ER20CF and 2M62M, for two basic reasons:

- due to lower capacity of locomotive 2M62M and, respectively, due to lower limit mass of the train; 

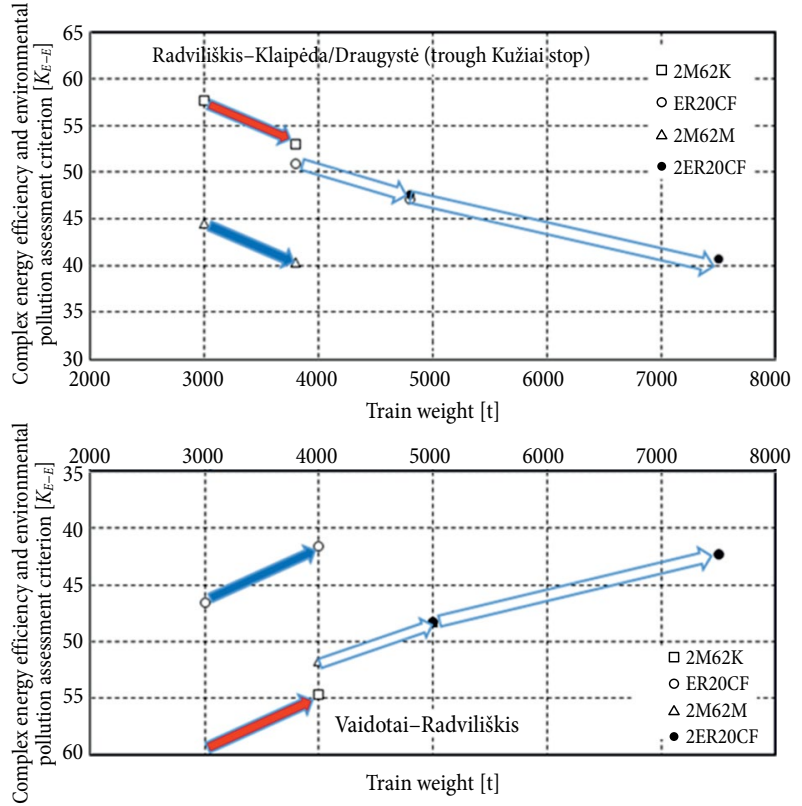

Fig. 6. Evaluation of energy efficiency on freight transportation line Vaidotai-Radviliškis-Klaipeda/Draugystè (via Kužiai station)

- due to a lower fuel economy indicator under operation conditions: the comparative effective fuel consumption at the maximum power mode was not lower than that of CAT 3512B-HD and MTU 4000R41 diesel engines; however, at partial load modes (standing for the basis of the operational load cycle) the values of diesel engine D $49 b_{e}$ are higher; additionally, $b_{e}$ was degrading due to a negative effect of transient modes on fuel economy; in case of diesel engines CAT 3512B-HD and MTU 4000R41, a negative effect of transient modes is minimized by the electronic control system.

Based on the results of the comparative emission studies, the stable dependence between comparative emissions and fuel consumption is observed. It is obvious that the emission of greenhouse gas $\mathrm{CO}_{2}$ and sulphur oxides is proportional to the mass of the burned fuel due to the natural composition of the fuel.

It is obvious that the selection of a locomotive type when carrying freight and the formation of the train weight in freight transportation lines should be carried out in order to reach the minimum $K_{E-E}$ value.

With respect to further research, the comparative fuel consumption per work unit $\mathrm{t} \cdot \mathrm{km}$ [ $\mathrm{kg}$ fuels $/ \mathrm{t} \cdot \mathrm{km}$ ] have been approved as the energy efficiency criterion (measuring such consumption in $[\mathrm{kJ} / \mathrm{t} \cdot \mathrm{km}]$ in the energy equivalent).

The main constituents of control, forecasting and improvement technology with a view to freight transportation energy and ecological indicators are as follows:

- steady fuel consumption control system of JSC 'Lithuanian Railways', a wide range of technological possibilities provided by the electronic control system of modern locomotive diesel engine models CAT 3512B-HD and MTU 4000R41;
- developed and adjusted software package for mathematical modelling of operational, energy and ecological indicators of locomotive diesel engines and extensive statistical data received by means thereof;

- in order to use measures to improve freight transportation operation indicators, the rational distribution of operated locomotive types in characteristic railway network lines and rational selection of transportation indicators (train weight, the structure of rolling stocks, etc.) are of importance.

Electronic systems used to control the technical condition of diesel engine assemblies and machines must be extended by covering the registration of energy characteristics of diesel engines during every ride.

The theoretical and experimental values of $K_{E-E}$ criterion in railway lines comparative analysis fragment is given in Fig. 7. There for it is rightly stated that $K_{E-E}$ mathematical modelling results adequately reflect the freight practical performance.

Data from one section of ER20CF locomotive can be evaluated in two ways:

- on the one hand, trends of the theoretical and actual values of the $K_{E-E}$ criterion are close as the differences between them and the two-section locomotives do not exceed $\pm 10 \%$;

- on the other hand, the actual $K_{E-E}=f(Q)$ trend characterized by significant dispersion of data from the summary line (red line Fig. 7); with increased train weight of $Q=3000$ to 3800 tons, the data scattering reaches $\pm 20 \div 25 \%$, while the lower range of the $Q$ virtually none; one possible reason for the instability of values of the criterion $K_{E-E}$ is use of one section locomotives in this railway line; it is not excluded that it could be influenced by different technical conditions of ER20CF locomotives, which naturally reduce the two sections 2ER20CF use case.

In the range of $2200 \div 3800$ tons of train weight, the value of $K_{E-E}$ criterion changes by $22 \%$ from $58 \mathrm{~kJ} / \mathrm{t} \cdot \mathrm{km}$ at $Q=2200 \mathrm{t}$ to $45 \mathrm{~kJ} / \mathrm{t} \cdot \mathrm{km}$ at $Q=3800 \mathrm{t}$, according to the generalized trend.

The performed assessments justify that on main railway lines, values of the energy efficiency and emissions reduction reserves criterion $K_{E-E}$ make up $6 \div 15 \%$.

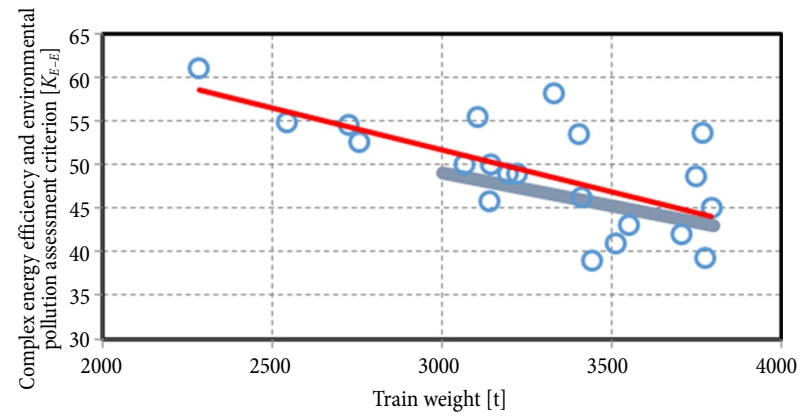

Fig. 7. Theoretical ant actual values of complex $K_{E-E}$ criteria values of a single section locomotive ER20CF on the railway line Radviliškis-Draugystè: o - operational experimental points; — - theoretical trend; — - actual data trend 
It must be noted that the ecological control of carriages and tasks to reduce harmful emissions could become as relevant as energy saving in the short term. It is likely that recently developed (and applied) microprocessor systems for registering harmful emissions will be used in the transport and railway sector under regulated standards.

\section{Principles for Control and Improvement of Freight Transportation Operated by the JSC 'Lithuanian Railways'}

Based on the conducted experimental and analytical calculation studies, the fuel economy indicator has been approved as the criterion for the evaluation of operation energy and ecological indicators of diesel engines of locomotives: fuel economy indicators of the operated locomotive fleet with the existing transportation infrastructure and planned freight circulation form fuel consumption and, comparatively, energy efficiency per work unit $[\mathrm{t} \cdot \mathrm{km}]$ - on the other hand, based on the conducted studies, where the comparative emission of harmful components $\mathrm{e}_{\mathrm{NOx}}, \mathrm{e}_{\mathrm{CO}}, \mathrm{e}_{\mathrm{CH}}, \mathrm{e}_{\mathrm{PM}}$ is basically independent of the train weight and largely of the freight transportation line, energy efficiency may be used to evaluate ecological indicators of operated locomotive diesel engines as well - energy consumption indicators unambiguously indicate the greenhouse gas $\mathrm{CO}_{2}$ emission as $\mathrm{CO}_{2}$ yield with a view to a certain type of fuels depends solely on fuel consumption.

This way, energy consumption comparative indicators in freight transportation lines of the JSC 'Lithuanian Railways' characterise energy efficiency when carrying freight in the certain direction by locomotives of operated types.

\section{Conclusions}

1. Based on integrated experimental research, approved by mathematical modelling, the $K_{E-E}$ criterion is used to evaluate the energy use efficiency during freight transportation. The $K_{E-E}$ criterion reflects the energy consumption (reflecting 1 unit of energy consumption for $10000 \mathrm{~km}$ of freight transportation), so it is rational to use the $K_{E-E}$ criterion values when organising rational freight transportation in order to reduce fuel and energy consumption.

2. The assessment of the energy efficiency of freight locomotives 2M62M and ER20CF/2ER20CF operated by the JSC 'Lithuanian Railways' using the experimental mathematical modelling research showed 6 to $15 \%$ reserve to reduce the fuel consumption in freight transportation.

3. It was found that harmful emissions $\left(\mathrm{CO}, \mathrm{NO}_{\mathrm{x}}, \mathrm{CH}\right.$, PM) per specific fuel consumption per unit mass [g/ $\mathrm{kg}$ of fuel] or [kg/t of fuel] in different types of locomotives and railway lines, change little depending on different mass of transported cargo in the analysed range of $3000 \div 7500 \mathrm{t}$. On this basis, the $K_{E-E}$ criterion is appropriate to use in optimising the rail freight transport (choosing a certain type of a locomotive line, constituting train weight), both in terms of energy and environmental performance indicators.

\section{References}

AB 'Lietuvos geležinkeliai'. 2003. Šilumvežiu ir dyzeliniu traukiniu dyzelino normu nustatymo metodika. Vilnius. (in Lithuanian).

Caterpillar. 2015. Locomotive Engine 3512B. Available from Internet: http://www.stet.pt/dl/LEHH0362.pdf

DieselNet. 2015. International: UIC Locomotive Emission Standards. Available from Internet: https://www.dieselnet. com//standards/inter/uic_loco.php

EC. 2013. EU Transport in Figures: Statistical Pocketbook 2013. 132 p. http://doi.org/10.2832/19314

EC. 2011. White Paper: Roadmap to a Single European Transport Area - Towards a Competitive and Resource Efficient Transport System. COM(2011) 144 final. 28.3.2011, Brussels. Available from Internet: http://eur-lex.europa.eu/legalcontent/EN/ALL/?uri=CELEX:52011DC0144

EC. 2003. Proposal for $f$ Directive of the European Parliament and of the Council on Energy End-Use Efficiency and Energy Services. Brussels, $\operatorname{COM}(2003) 739$ final, 2003/0300 (COD), 10.12.2003. 39 p. Available from Internet: http://eur-lex.europa.eu/LexUriServ/LexUriServ. do?uri=COM:2003:0739:FIN:EN:PDF

Eggleston, S.; Walsh, M. 2000. Emissions: energy, road transport, in Good Practice Guidance and Uncertainty Management in National Greenhouse Gas Inventories. Intergovernmental Panel on Climate Change (IPCC), 55-70. Available from Internet: http://www.ipcc-nggip.iges.or.jp/public/gp/ bgp/2_3_Road_Transport.pdf

González-Gil, A.; Palacin, R.; Batty, P.; Powell, J. P. 2014. A systems approach to reduce urban rail energy consumption, Energy Conversion and Management 80: 509-524. http://doi.org/10.1016/j.enconman.2014.01.060

González-Gil, A.; Palacin, R.; Batty, P. 2013. Sustainable urban rail systems: strategies and technologies for optimal management of regenerative braking energy, Energy Conversion and Management 75: 374-388.

http://doi.org/10.1016/j.enconman.2013.06.039

Homich, A. Z. 1987. Toplivnaja jeffektivnost' $i$ vspomogatel'nye rezhimy teplovoznyh dizelej. Moskva: Transport: 271 s. (in Russian).

IMO. 2009. Second IMO GHG Study 2009. International Maritime Organization (IMO). 240 p. Available from Internet: http://www.imo.org/en/OurWork/Environment/PollutionPrevention/AirPollution/Documents/GHGStudyFINAL. pdf

ISO 8178-9:2012. Reciprocating Internal Combustion Engines. Exhaust Emission Measurement.

Katsanos, C. O.; Hountalas, D. T.; Zannis, T. C. 2013 Simulation of a heavy-duty diesel engine with electrical turbocompounding system using operating charts for turbocharger components and power turbine, Energy Conversion and Management 76: 712-724.

http://doi.org/10.1016/j.enconman.2013.08.022

Kirschstein, T.; Meisel, F. 2015. GHG-emission models for assessing the eco-friendliness of road and rail freight transports, Transportation Research Part B: Methodological 73: 13-33. http://doi.org/10.1016/j.trb.2014.12.004 
Kolomensky Zavod. 2015. Production of the PJSC 'Kolomensky Zavod'. Available from Internet: http://www.kolomnadiesel. com/eng/productions

Lebedevas, S. 2002. Energetinių išteklių išsaugojimas geležinkelio transporte, tobulinant šilumvežių dyzelių eksploatacines kuro suvartojimo charakteristikas, Transport 17(1): 30-37. (in Lithuanian).

Lebedevas, S.; Dailydka, S.; Jastremskas, V.; Rapalis, P. 2015. The influence of locomotive diesel engine transient operating modes on energy usage, Transportation Research Part D: Transport and Environment 34: 219-229. http://doi.org/10.1016/j.trd.2014.10.011

Li, M.; Cui, H.; Wang, J.; Guan, Y. 2009. Improvement of fuel injection system of locomotive diesel engine, Journal of Environmental Sciences 21(1): S139-S141. http://doi.org/10.1016/S1001-0742(09)60058-9

Lingaitis, L. P.; Lebedevas, S.; Liudvinavičius, L. 2014. Evaluation of the operational reliability and forecasting of the operating life of the power train of the freight diesel locomotive fleet, Eksploatacja i Niezawodność - Maintenance and Reliability 16(1): 73-79.

LR AM. 2011a. Lietuvos Respublikos aplinkos ministro įsakymas „Dèl aplinkos ministro $2003 \mathrm{~m}$. gruodžio $24 \mathrm{~d}$. isakymo Nr. 715 „Dèl teršalų, išmetamu ị atmosfera iš šilumvežiu ir dyzeliniu traukiniu, vertinimo metodikos LAND 18-2003/M03 patvirtinimo" pakeitimo". $2011 \mathrm{~m}$. birželio 29 d. Nr. D1531, Vilnius. (in Lithuanian).

LR AM. 2011b. Lietuvos Respublikos aplinkos ministro įsakymas „Dèl iš geležinkeliu riedmenu su dyzeliniais vidaus degimo varikliais į aplinkos ora išmetamo teršalų kiekio skaičiavimo metodikos LAND 18-2011 patvirtinimo“. $2011 \mathrm{~m}$. birželio 29 d. Nr. D1-531, Vilnius. (in Lithuanian).

MPS RF. 1997. Metodika analiza rezul'tatov rashoda toplivnojenergeticheskih resursov na tyagu poezdov. CTD-26. Ministerstvo putej soobshheniya Rossijskoj Federacii (MPS RF). Moskva. 94 s. (in Russian).

MPS SSSR. 1967. Instrukciya po tehnicheskomu normirovaniyu rashoda jelektricheskoj jenergii i topliva teplovozami na tyagu poezdov. CT/2564. Ministerstvo putej soobshheniya SSSR (MPS SSSR). Moskva. (in Russian).

Parovoz IS. 2015. Karta zheleznyh dorog SNG i Pribaltiki. Kartograficheskaya kollekciya "Parovoz IS" ["Steam Engine IS" Map Collection]. Available from Internet: http://www.parovoz.com/maps/supermap (in Russian).

Rakopoulos, C. D.; Dimaratos, A. M.; Giakoumis, E. G.; Rakopoulos, D. C. 2010. Investigating the emissions during acceleration of a turbocharged diesel engine operating with bio-diesel or n-butanol diesel fuel blends, Energy 35(12): 5173-5184. http://doi.org/10.1016/j.energy.2010.07.049

Rakopoulos, C. D.; Giakoumis, E. G. 2009. Diesel Engine Transient Operation: Principles of Operation and Simulation Analysis. Springer. 390 p. http://doi.org/10.1007/978-1-84882-375-4

Shancita, I.; Masjuki, H. H.; Kalam, M. A.; Rizwanul Fattah, I. M.; Rashed, M. M.; Rashedul, H. K. 2014. A review on idling reduction strategies to improve fuel economy and reduce exhaust emissions of transport vehicles, Energy Conversion and Management 88: 794-807. http://doi.org/10.1016/j.enconman.2014.09.036

Simson, A. Je.; Homich, A. Z.; Kuric, A. A. 1987. Teplovoznye dvigateli vnutrennego sgoraniya. Moskva: Transport. $536 \mathrm{~s}$. (in Russian).
Statistics Lithuania. 2015. Transportas ir ryšiai. Available from Internet: http://db1.stat.gov.lt/statbank/selecttable/omrade 0 .asp ?SubjectCode $=$ S7\&PLanguage $=0 \&$ ShowNews $=\mathrm{O}$ FF (in Lithuanian).

Vossloh North America. 2015. Locomotives. Available from Internet: http://www.vossloh-north-america.com/en/locomotives/diesel_electric_locomotives/ve_4500p/ve_4500p.html

Winther, M. 2008. Fuel Consumption and Emissions from Navigation in Denmark from 1990-2005 - and Projections from 2006-2030. NERI Technical Report No. 650. National Environmental Research Institute (NERI), University of Aarhus, Denmark. 112 p. Available from Internet: http://www.dmu. $\mathrm{dk} / \mathrm{pub} / \mathrm{fr} 650 . \mathrm{pdf}$ 